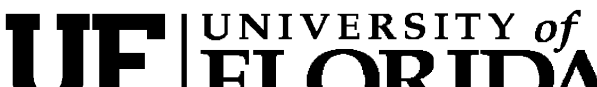 FLORIDA \\ IFAS Extension
}

\section{Chill Accumulation Monitoring and Forecasting ${ }^{1}$}

\section{Clyde W. Fraisse and Alicia Whidden ${ }^{2}$ \\ Introduction}

Most temperate plants including orchard crops and deciduous trees enter a dormant period during late fall and winter characterized as a state of reduced or stopped metabolic activity of above ground parts. The development of dormancy and cold hardiness is a gradual process which begins in late fall or early winter in Florida (Lyrene and Williamson, 2004). Dormancy enables plants to tolerate freezing temperatures and prevents growth during mid-winter warm spells. Once dormant, plants require accumulated exposure to cool temperatures for budbreak and the resumption of normal growth in the spring. The amount of accumulated cool temperature exposure required for normal growth varies by species and cultivar and is referred to as chilling requirement.

All economically important fruit and nut tree species that originated from temperate and cool subtropical regions have chilling requirements that have to be fulfilled each winter to ensure homogeneous flowering, adequate fruit set, and economically sufficient yields (Luedeling et al., 2009). Each species and cultivar has its own specific chilling requirement that can be measured either by the accumulated hours below a chilling temperature threshold or by cumulative chill units, which are hours that are weighted for temperature effects at breaking dormancy. According to Byrne and Bacon (2004), insufficient chilling may result in one or more of the following physiological symptoms: a) delayed foliation, b) reduced fruit set and increased buttoning, and c) reduced fruit quality.

Growers in Florida can now track and forecast chill accumulation during the winter season by using a web-based tool on AgroClimate.org (http://agroclimate.org/tools/ChillAccum/). AgroClimate.org is a climate forecast and decision support system (Fraisse et al., 2006) developed by the Southeast Climate Consortium (SECC) in partnership with the Cooperative State Extension Service (http://seclimate.org). The main purpose of AgroClimate is to help agricultural producers reduce risks associated with climate variability in the southeastern U.S.A.

\section{Chill Accumulation Models}

Estimating the amount of chilling accumulation requires the definition of what temperatures are needed to satisfy chilling requirements. Most people agree that temperatures below $32^{\circ} \mathrm{F}\left(0^{\circ} \mathrm{C}\right)$ or above $60^{\circ} \mathrm{F}\left(15.5^{\circ} \mathrm{C}\right)$ are not effective. Using blueberries

1. This document is AE452, one of a series of the Agricultural and Biological Engineering Department, Florida Cooperative Extension Service, Institute of Food and Agricultural Sciences, University of Florida. Original publication date January 2010. Visit the EDIS website at http://edis.ifas.ufl.edu.

2. Clyde W. Fraisse, assistant professor, Department of Agricultural and Biological Engineering; Florida Cooperative Extension Service, Institute of Food and Agricultural Sciences, University of Florida, Gainesville, FL 32611.

The Institute of Food and Agricultural Sciences (IFAS) is an Equal Opportunity Institution authorized to provide research, educational information and other services only to individuals and institutions that function with non-discrimination with respect to race, creed, color, religion, age, disability, sex, sexual orientation, marital status, national origin, political opinions or affiliations. U.S. Department of Agriculture, Cooperative Extension Service, University of Florida, IFAS, Florida A. \& M. University Cooperative Extension Program, and Boards of County Commissioners Cooperating. Millie Ferrer-Chancy, Interim Dean 
as an example, temperatures between $32^{\circ} \mathrm{F}$ and $45^{\circ} \mathrm{F}$ appear to be the most effective at satisfying the chilling requirements, but temperatures between $45^{\circ} \mathrm{F}$ and $55^{\circ} \mathrm{F}$ also contribute to chilling and temperatures above $70^{\circ} \mathrm{F}$ between mid-November and mid-February probably negate some chilling (Lyrene and Williamson, 2004). Both the concepts of chill hours and chill units can be used for predicting the breaking of dormancy (Cesaraccio et al., 2004).

\section{Chill Hours}

Chilling hours $(\mathrm{CH})$ are generally determined in two different ways:

\section{Number of hours below $45^{\circ} \mathrm{F}\left(7^{\circ} \mathrm{C}\right)$}

2. Number of hours with air temperature between $45^{\circ} \mathrm{F}$ and $32^{\circ} \mathrm{F}$.

Producers generally use the concept of chill hours to estimate chill accumulation during late fall and winter because they are relatively easy to calculate.

\section{Chill Units}

In the case of chill units $(\mathrm{CU})$ the hours are weighted for their effectiveness of satisfying chilling requirements depending on the temperature. Classical chill unit methods for predicting the breaking of dormancy include the "Utah" model (Richardson et al., 1974), the "North Carolina" model (Shaultout and Unrath, 1983), the "Low Chilling" model (Gilreath and Buchanan, 1981), and the Positive Chill model (Linsley-Noakes et al., 1995). The weighting factors for the classical chill unit models (Table 1) were mainly determined in laboratory tests and differ because they were derived using different species and varieties. The Utah model used Redhaven and Elberta peach, the North Carolina model used Starkrimson delicious apple, and the Low Chilling model used Sungold nectarine.

Chill units are calculated in AgroClimate.org for strawberry, blueberry Aliceblue (Figure 1), Blueberry Tifblue, and peach, using an adaptation of the Utah Model with different temperature ranges and thresholds (Table 2). No negation is accounted for temperatures outside the range.

\section{Chill Accumulation Tool on AgroClimate.org}

The information available in the AgroClimate.org Chill Accumulation Tool includes the monitoring and forecasting of chill accumulation from October $1^{\text {st }}$ to April 30 in all weather stations that belong to the Florida Automated Weather Network (FAWN) in the State of Florida and to the Georgia Automated Environmental Monitoring Network (GAEMN) in Georgia.

The Chill Accumulation Tool, when loaded, shows chill accumulation up to the current date observed at the weather station that is the closest to the selected county (Figure 2). FAWN weather stations have temperature sensors installed at $2 \mathrm{~m}$ $(6.56 \mathrm{ft})$ and at $60 \mathrm{~cm}(1.97 \mathrm{ft})$. The tool to calculate chill accumulation uses temperatures measured by the 2 -meter sensor. The default model is in number of hours with air temperature between $45^{\circ} \mathrm{F}$ and $32^{\circ} \mathrm{F}$ but the user can select number of hours below $45^{\circ} \mathrm{F}$ or chill units. The projection cone beyond the last observation represents the possible range of chill accumulation predicted for the current climate $\mathrm{El}$ Niño Southern Oscillation (ENSO) phase . The color of the projection cone indicates if the forecast is for El Niño (red), La Niña (blue), or neutral (green) phases.

Chill accumulation is presented in two different graphs; the top one shows the cumulative chill in the current winter season since October $1^{\text {st }}$. The bottom graph (bar graph) shows the bi-weekly accumulation during the same time period. The user can also check the options that are available above the top graph to visualize the historical average chill accumulation observed at the selected county and the accumulation observed during the past winter season.

The chill accumulation tool will only display the number of accumulated chill hours or chill units during the current season if the tool is accessed between October $1^{\text {st }}$ and April 30. During the remaining of the year users can only visualize the prediction for the next season as well as the historical average and total accumulated during the past season. 


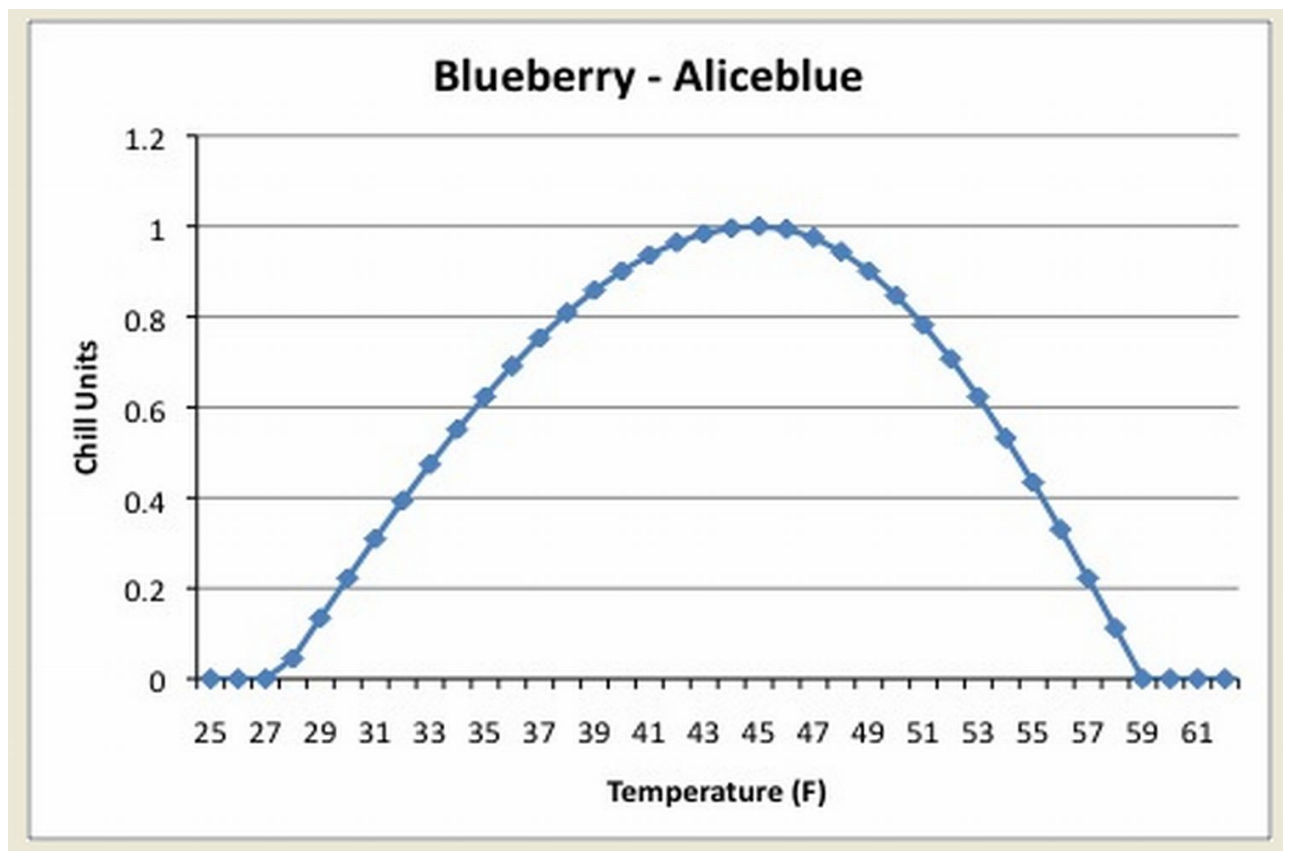

Figure 1. Chill units accumulation as calculated in AgroClimate (Blueberry Aliceblue) with optimal temperature at $45{ }^{\circ} \mathrm{F}$ and no negation given to temperatures warmer than $59^{\circ} \mathrm{F}$.

The different intensities of the colored background in the projection cone indicate the $50 \%$ and the $80 \%$ probabilities. The $50 \%$ probability (darker background) shows the range of chill accumulation observed during 5 out of 10 years of the selected ENSO phase. The $80 \%$ probability (lighter background) shows the range observed during 8 out of 10 years. Figure 3 shows an example for neutral years in Alachua County.

By clicking on the "Graph all" button the user can visualize in a separate window the total and bi-weekly accumulations for all ENSO phases and also for all years on record.

Users can select other stations in the vicinities of the selected county by modifying the distance from the central location of the county to a maximum of 70 miles (Figure 4). This flexibility allows users to select stations that are closer to their farm than the default station selected to each county.

\section{Conclusions}

The AgroClimate.org Chill Accumulation tool helps producers in Florida monitor and forecast chill accumulation during the winter season using either

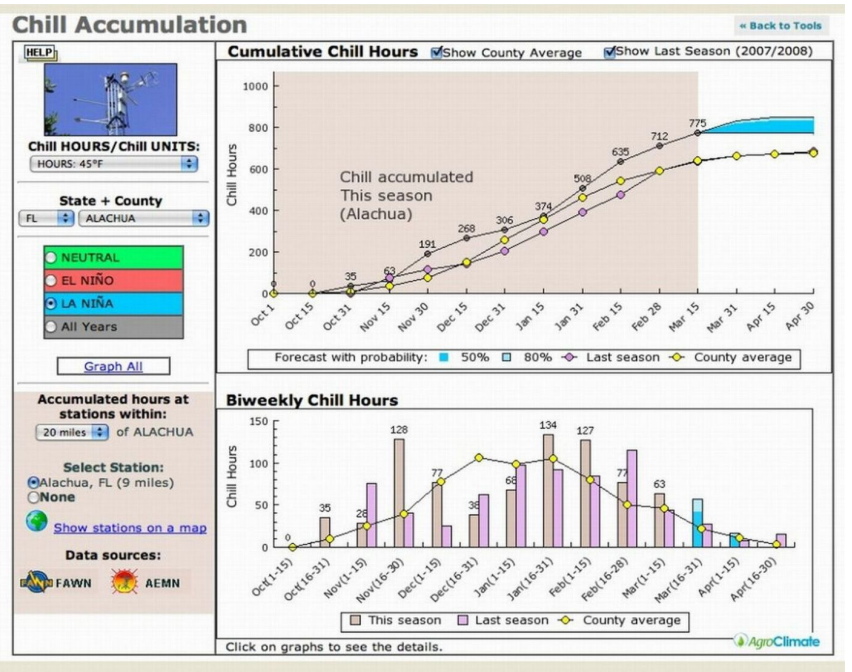

Figure 2. Chill accumulation tool showing the amount of chill (hours below 45] $F$, from October 1st to March 15th) observed at Alachua County, FL during the winter of 2008/09. It can be noticed that more chill (775 hours) was accumulated in comparison to the average for La Niña years and the amount accumulated in 2007/08.

chill hours or chill units models. It updates the amount of chill accumulated at selected FAWN weather stations in Florida and GAEMN stations in Georgia between October 1st and April 30th of each season. Users can also compare current and forecast accumulation levels with the long term average for 


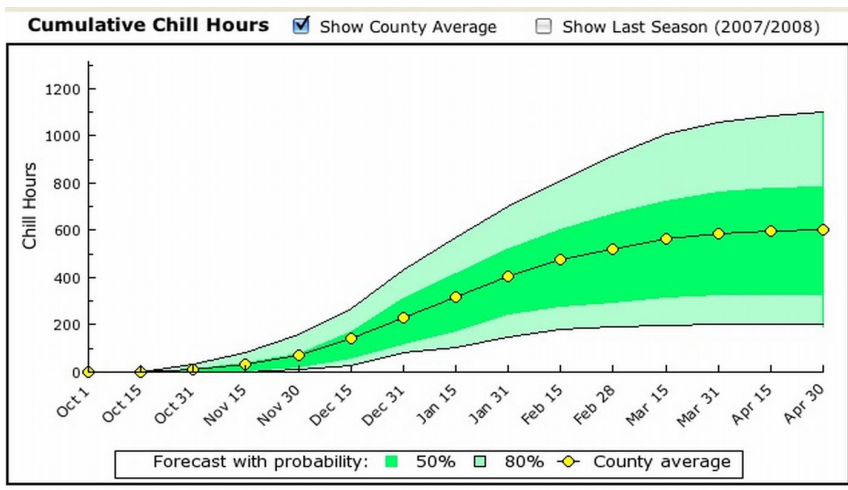

Figure 3. Chill accumulation prediction for Alachua County, Florida, during neutral years for the $50 \%$ (darker green cone) and $80 \%$ (lighter green cone) probability levels.

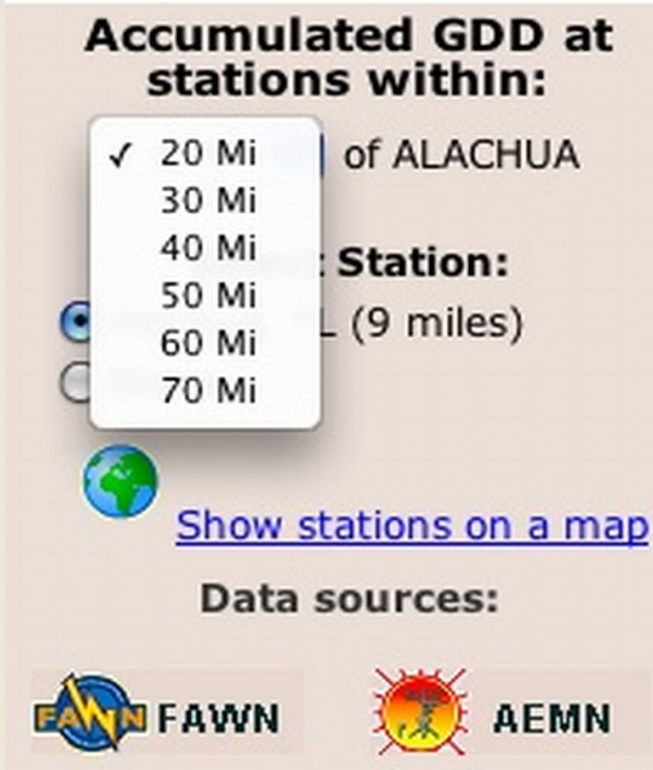

Figure 4. Users can select weather stations within distances up to 70 miles from the center of the county to visualize the number of chill hours accumulated during the current and/or past winter seasons.

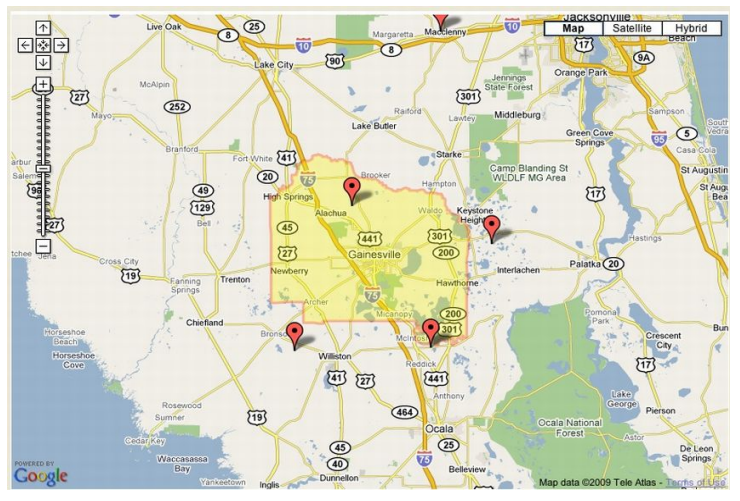

Figure 5. Shows an example of weather stations located within 50 miles of the center of Alachua County (Alachua, Citra, Putnam Hall, Bronson, and Macclenny). the selected county and with the amount of chill accumulated during the last winter season.

\section{References}

Byrne, D.H. and T. Bacon. 2004. Chilling accumulation: Its importance and estimation. Texas A\&M Stone Fruit Breeding Program, available online at:

http://aggie-horticulture.tamu.edu/stonefruit/ apopart.htm

Cesaraccio, C., D. Spano, R. L. Snyder, and P. Duce. 2004. Chilling and forcing model to predict bud-burst of crop and forest species. Agricultural and Forest Meteo. 126: 1-13.

Fraisse, C.W., Breuer, N.E., Zierden, D., Bellow, J.G., Paz, J., Cabrera, V.E., Garcia y Garcia, A., Ingram, K.T., Hatch, U., Hoogenboom, G., Jones, J.W., O'Brien, J.J. 2006. AgClimate: A climate forecast information system for agricultural risk management in the southeastern USA, Computers and Electronics in Agriculture, Volume 53, (2006):13-27.

Gilreath, P. and D. Buchanan. 1981. Rest prediction model for low chilling Sungold nectarine. J. Amer. Soc. Hort. Sci. 106(4):426-429.

Linsley-Noakes, G.C., M. Louw, and P. Allan. 1995. Estimating daily positive Utah chill units using daily maximum and minimum temperatures. J. S. Afr. Soc. Hort. Sci. 5(1):19-22.

Luedeling, E., M. Zhang, and E.H. Girvetz. 2009. Climatic changes lead to declining winter chill for fruit and nut trees in California during 1950-2009. PlosOne 4(7):e6166.

Lyrene, P. M., and J. G. Williamson. 2004. Protecting blueberries from freezes in Florida. Institute of Food and Agricultural Sciences, Publication HS968. Florida Cooperative Extension Service, Gainesville, FL.

Richardson, E. A., S. D. Seeley, and D. R. Walker. 1974. A model for estimating the completion of rest for Redhaven and Elberta peach trees. HortScience 9(4): 331-332. 
Shaultout, A. D., and C. R. Unrath. 1983. Rest completion prediction model for Starkrimson Delicious apples. J. Am. Soc. Hort. Sci. 108 (6), 957-961. 
Table 1. Temperature conversion to chill unit factors for the Utah, North Carolina, and Low Chilling models. Adapted from Cesaraccio et al. (2004).

\begin{tabular}{||l|l|l|l|l|l||}
\hline \multicolumn{2}{||l|l|l|l||}{} & \multicolumn{2}{l|}{ North Carolina Model } & \multicolumn{2}{l||}{ Low Chilling Model } \\
\hline Temp $(F)$ & CU & Temp $(F)$ & CU & Temp (F) & CU \\
\hline$<35$ & 0.0 & $<35$ & 0.0 & $<35.2$ & 0.0 \\
\hline $35-36.5$ & 0.5 & $35-45$ & 0.5 & $35.2-46.2$ & 0.5 \\
\hline $\begin{array}{l}36.5- \\
48.6\end{array}$ & 1.0 & $45-55.4$ & 1.0 & $46.2-57.2$ & 1.0 \\
\hline $\begin{array}{l}48.6- \\
54.5\end{array}$ & 0.5 & $55.4-61.7$ & 0.5 & $57.2-62.6$ & 0.5 \\
\hline $\begin{array}{l}54.5- \\
60.8\end{array}$ & 0.0 & $61.7-66.2$ & 0.0 & $62.6-67.1$ & 0.0 \\
\hline $\begin{array}{l}60.8- \\
64.4\end{array}$ & -0.5 & $66.2-69.3$ & -0.5 & $67.1-70.7$ & -0.5 \\
\hline$>64.4$ & -1.0 & $69.3-71.8$ & -1.0 & $>70.7$ & -1.0 \\
\hline & & $71.8-74$ & -1.5 & & \\
\hline & $>74$ & -2.0 & & \\
\hline \hline
\end{tabular}

Table 2. Temperature ranges $\left({ }^{\circ} \mathrm{F}\right)$ used for chill units calculation on AgroClimate.org.

\begin{tabular}{||l|l|l|l||}
\hline \hline Crop & $\begin{array}{l}\text { Min Temp. } \\
\left({ }^{\circ} \mathrm{F}\right)\end{array}$ & $\begin{array}{l}\text { Optimal Temp } \\
\left({ }^{\circ} \mathrm{F}\right)\end{array}$ & $\begin{array}{l}\text { Max. Temp } \\
\left({ }^{\circ} \mathrm{F}\right)\end{array}$ \\
\hline Strawberry & 32.0 & 45.0 & 68.0 \\
\hline Blueberry - Aliceblue & 27.5 & 45.0 & 59.0 \\
\hline Blueberry - Tifblue & 29.8 & 44.1 & 55.2 \\
\hline Peach & 28.4 & 42.8 & 57.2 \\
\hline \hline
\end{tabular}

